DOI: $10.17516 / 1997-1370-0819$

УДК 373.54-056.266

\title{
Inclusive Education in Practice: Teachers' Opinions and Needs
}

\author{
Vlasta Belková, Patrícia Zólyomiová \\ and Štefan Petrík* \\ Matej Bel University \\ Banska Bystrica, Slovakia
}

Received 08.06.2021, received in revised form 14.07.2021, accepted 10.08.2021

\begin{abstract}
The paper presents a part of the research data from a broader piece of research focused on teaching effectiveness in inclusive forms. It analyses the opinions of the teaching staff at different types of schools on the existing barriers and teachers' needs related to inclusive education. The research involved $\mathrm{N}=1.216$ teaching staff ( $98 \%$ teachers) working in Slovak schools. A questionnaire developed by the authors was used and respondents filled it in anonymously in electronic form. The results clearly indicate persistent issues in the inclusive practice, which are in line with the findings of other nation-wide Studies, i. e., missing multidisciplinary teams at schools, too many students in a single form, lack of teaching and specialised staff, limited offer of educational programmes focused on further education.
\end{abstract}

Keywords: teacher, student with special educational needs, inclusive environment, barrier, need, teacher training.

The presented findings are a part of the research project entitled KEGA No. 046UMB-4/2018 «Ako rozumieme inkluzívnej edukácii? Tvorba optimálneho výučbového modelu» [«How Do We Understand Inclusive Education? Creating an Optimal Model of Teaching»].

Research area: pedagogy.

Citation: Belková, V., Zólyomiová, P., Petrík, Š. (2021). Inclusive education in practice: teachers' opinions and needs. J. Sib. Fed. Univ. Humanit. soc. sci., 14(9), 1286-1298. DOI: 10.17516/1997-1370-0819

(C) Siberian Federal University. All rights reserved

* Corresponding author E-mail address: stefan.petrik@umb.sk 


\title{
Инклюзивное образование на практике: мнения и потребности учителей
}

\author{
В. Белкова, П. Зольомиова, Шт. Петрик \\ Университет Матея Бела \\ Банска-Бистрица, Словакия
}

\begin{abstract}
Аннотация. В статье представлена часть данных более широкого исследования, посвященного эффективности преподавания в инклюзивных формах. Анализируется мнение преподавательского состава различных типов школ о существующих препятствиях и потребностях учителей, связанных с инклюзивным образованием. В исследовании участвовали $\mathrm{N}=1,216$ преподавателей (98 \% учителей), работающих в словацких школах. Использовалась разработанная авторами анкета, которую респонденты анонимно заполнили в электронной форме. Результаты указывают на существование регулярных проблем в инклюзивной практике, которые согласуются с выводами других общенациональных исследований, например, отсутствие мультидисциплинарных групп в школах, большое количество учеников в одном классе, нехватка преподавателей и специализированного персонала, ограниченное предложение образовательных программ, ориентированных на дальнейшее образование.
\end{abstract}

Ключевые слова: учитель, ученик с особыми образовательными потребностями, инклюзивная среда, барьер, потребность, подготовка учителей.

Представленные результаты являются частью исследовательского проекта под названием KEGA № 046UMB - 4/2018 «Ako rozumieme inkluzívnej edukácii? Tvorba optimálneho výučbového modelu « [«Как мы понимаем инклюзивное образование? Создание оптимальной модели обучения»]

Научная специальность: 13.00.00 - педагогические науки

\section{Introduction}

The needs of the most vulnerable groups of population, which includes children and youth with a health disadvantage, are identical as confirmed by the Správa o potrebách detía mladých ludí v meste Banská Bystrica (Report on the Needs of the Children and Youth in the Banská Bystrica City). The report has focused on the children with special needs as well, specifically those with a health disadvantage (Brozmanová Gregorová et al., 2017). These needs include "the need to be accepted by the collective and supported by the surroundings as well as society, the need for self-awareness, trust and patience, and the opportunity to spend free time with healthy peers...» (Brozmanová Gregorová et al., 2017, p. 92). The needs of children and youth with a health disadvantage to spend time with their healthy peers indicate that inclusion affects everyone and is not limited to people with special needs. In formal education, the quality of the educational environment is not measured only by the material and equipment, but also by accepting all students without discrimination. At the same time, it is desirable to ensure the provision of necessary staff who can appropriately saturate different needs in children.

\section{Inclusive environment from \\ the viewpoint of the school management}

The European Agency for Development in Special Needs Education (2014) has stated that diversity in the context of formal education is a natural phenomenon, i. e., the diversity of students and their needs is common. Different students' needs are saturated efficiently and on purpose if the school management is inclined to introduce the principles of inclusive education. 
The governing body of the school is considered the main stakeholder in the transformation of schools towards inclusiveness (Riehl, et al. 2008; MacFarlane \& Woolfson, 2013; Janoško \& Neslušanová, 2014, p. 77). Besides the school management, there are other staff on whom the practical application of the inclusive principles into the school environment depends. A quality, inclusive educational environment can be created if the main stakeholders in education appropriately cooperate. If there is cooperation, better conditions for all students can be secured. The implementation of inclusive education should be perceived as a collective/ team activity in which different participants are responsible for performing the tasks within their own scope of activity (EASIE, 2012, p. 22). The support needed by teachers to perform their tasks in the classrooms includes access to the structures facilitating communication and cooperation with a team of experts as well as opportunities for continuous professional development (European Agency for Development in Special Needs Education, 2012, p. 22). Another important role is played by the cooperation and coordination of experts, i. e., networking with the aim to provide interdisciplinary community service (ibid).

\section{The teacher}

\section{and the inclusive school environment}

«The trend of inclusive education has found most of our teachers unprepared in terms of personality development as well as knowledge (Leonhardt \& Lechta et al., 2006). «University teacher training takes the traditional form, while the postgraduate and continuous teacher education is relatively weak and does not reflect the up-to-date requirements «(Janoško \& Neslušanová, 2014, p. 50). The OECD TALIS international teacher testing (Teaching and Learning International Survey focused on the teachers and school management to collect information about their work conditions and the learning environment at schools) results from 2018 are available. The last measurement at 182 primary schools and 8-year grammar schools involving approx. 3,300 employees teaching at ISCED2 level (NÚCEM, 2018) took place between (30/4-11/5/2018). Further nation-wide research was performed in Slovakia by MESA (an independent nonprofit NGO promoting reforms) (https://todarozum.sk/\#oprojekte), The Learning Makes Sense project has provided an overview of the Slovak education system including the teachers' readiness to work in an inclusive environment (https://todarozum.sk). It was found that the readiness of Slovak teachers has not improved across the reporting periods (2008, 2013, 2018) (Koršňáková \& Kováčová, 2010, p. 57). NÚCEM, Press release on main findings, TALIS2018 Slovakia, p. 3; Basic information on the OECD TALIS2013 results, $p$. 6). The authors partially addressed this issue before (Belková et al. 2018, 2019). According to EASIE, teachers face difficulties in the inclusive environment if their actual competences are not optimal (European Agency for Development in Special Needs Education, 2014b).

\section{The barriers and teachers' needs}

\section{in the inclusive environment}

A barrier refers to an obstacle that needs to be overcome to achieve the goal (SR Ministry of Finance, p. 10). Barriers in teaching refer to facts and phenomena that prevent teachers from performing their work properly or the aspects that are perceived by the teachers themselves as such.

Educational barriers differ according to the target groups. For instance, G. D'hertefelt (2000, in Machalová, 2018) has identified the following barriers in the adult clients of social work as a target group: informational, situational, institutional, and psychological. Miles $(2000$, p. 1) has explained that the lack of resources is a barrier for inclusion across the cultural, geographic, and economic borders; the resources include human and material (financial) resources, access to information and knowledge, but mainly the people's attitude to their exploitation. Miles (2000) considers the last one of key importance for promoting inclusive education.

In Slovakia, barriers for inclusion have been identified at the selected primary schools (State School Inspection - SSI: Report on the Promotion of Inclusive Education for Primary School Pupils in the 2018/2019 School Year and Learning Makes Sense, 2018 performed 
by MESA10). Upon comparison, identical and specific barriers have been found:

- In terms of developing an inclusive culture, some schools have failed to understand the idea of inclusive education in its complexity (they still confuse inclusion and integration of students with health disadvantages), other have not embraced the idea of inclusion at all (SSI, 2018/2019). Similar issues have been identified in different countries as well (Lishuai Jia \& M. Santi, 2020).

- In terms of further education and teachers' professional development, the available educational programmes have been found problematic. The offer of quality, relevant educational programmes (including those focused on working with students with special educational needs, i. e., SEN students) is insufficient. Moreover, the costs related to further education are high and relevant programmes are often cancelled (SSI, 2018/2019; Miškolci, Learning Makes Sense project). The lack of specialised knowledge and insufficient teaching abilities have also been identified as barriers by Rajovic \& Jovanovic (2013), Cologon (2013), and Lishuai Jia \& M. Santi (2020). Lishuai Jia \& M. Santi (2020) have also pointed out that the workload standards are unclear while the workload generated by forms with integrated SEN students is significantly increased in reality.

- The schools remain severely understaffed: the number of teaching and specialised staff needed is much smaller than their actual number (SSI, 2018/2019). Lishuai Jia $\&$ M. Santi (2020) have also pointed out that special education services and research are also lacking. In the SR, schools lack multidisciplinary teams, which seem to be essential for providing inclusive environments. It is important that all team members are autonomous, but respect each other, learn to cooperate and help each other, and develop their own procedures and strategies, i. e., a good working climate. It can be characterised as follows: 1) constructive criticism without unnecessary emotions, 2) absence of competitiveness, 3) lots of mutual assistance (Vančíková \& Sabo et.al., 2018, p. 93).

- Teachers describe the current state as generating «too much other work» (Miškolci, Learning Makes Sense project).

\section{Methods}

The overall goal of the project was to identify the efficiency of teaching in inclusive forms. The objectives included collecting teachers' opinions on the barriers and their own needs related to inclusive education in practice. In the broader research project, the empirical data were collected using a questionnaire developed by the authors, which incorporated a modified version of the "Teacher Efficacy for Inclusive Practices» (TEIP) Scale (Sharma, Loreman \& Forlin, 2012) standardised instrument. The items in the questionnaire were modified for the purpose of this research, specifically, open questions were added for the respondents to provide their own opinion. There were 25 items in total. This paper presents the results achieved by processing the selected demographic items of the questionnaire, which required the respondents to provide their own opinion. The following research questions were formulated:

RQ1: What are the barriers for inclusive education referred to by the teaching staff?

RQ2: What could help the teaching staff improve their working conditions in the inclusive environment?

RQ3: What do the teaching staff propose changing in the university teacher training?

Based on these research questions, the following items requiring the respondents to formulate their own opinions were created.

Types of barriers for inclusive education according to the teaching staff - this item measured how the respondents perceived this aspect. This item was formulated based on the fact that school systems aim to proceed from integration towards inclusion. However, true inclusion assumes changes in perception and organisation of the whole school system and educational environment, i. e., focusing on diverse educational needs and abilities to address all students. This kind of shift requires a major reform of educational policies (Körnerová, et al., online, Introduction), theoretical research of inclusion, and gradual development of an inclusive education system (Špotáková, Kundrátová, Štefková, Vojtová \& Zikmund Perašínová, 2018). If the aforementioned requirements are not met, teaching and specialised 
staff come across barriers when they strive to implement inclusive education in practice.

The next item including an open answer was What helps the teaching staff implement inclusive education in practice the most? This item was formulated based on the fact that inclusive education is perceived as education accessible to all, it provides flexible solutions, which can be adapted for every individual regardless of their preferred learning or communication style, or other specific needs (Čerešňová \& Rollova, 2015 in Čerešňová et al., 2018, pp. 13-14). Facilitating an inclusive education process is not easy, proper set-up and supporting mechanisms are necessary for teachers and specialised staff alike.

According to EASIE report entitled Key Principles of Promoting Quality in Inclusive Education (2011, p. 15), teaching students at universities are supposed to develop knowledge, skills, and understanding necessary for their own self-confidence as well as the ability to efficiently address different needs of their students. The Teacher Education for Inclusion Across Europe - Challenges and Opportunities report (EASIE, 2011, p. 18) has pointed out that the structure of university teacher education needs to be improved in terms of inclusion. The way future teachers are prepared for their profession needs a change (EASIE, 2014, p. 16). Based on these reports, the third item was formulated: What changes are necessary in university teacher education to improve the competences related to integrated education and in inclusion. In this case, experienced teachers were asked to provide their ideas on how university teacher training should be improved to prepare the graduates for integrated education and inclusion. Since some of the respondents have direct experience with teaching SEN students, the goal of this item was to collect their ideas and recommendations on how to improve the teacher training.

\section{Characteristics}

\section{of the research sample}

The research file consisted of $\mathrm{N}=1,216$ teaching staff employed at primary and high schools in the SR. In total, $\mathrm{N}=1,379$ answers were collected. Available selection was applied to select the respondents. The composition of respondents involved in the survey in terms of their workplace can be seen in Table 1 .

As can be seen, the largest part of the research file included primary school teachers and high school teachers respectively (62\% and $23 \%$ ). $79 \%$ of the respondents worked at state schools. Respondents from all regions of Slovakia were involved, most of them from Banská Bystrica (16 \%), Prešov (19\%), and Košice $(17 \%)$ regions. The majority of respon-

Table 1. Composition of the research sample in terms of the workplace (teaching staff)

\begin{tabular}{|l|c|c|}
\hline & $\mathrm{N}$ & $\%$ \\
\hline Primary school - 1st stage & 386 & 31.74 \\
\hline Primary school - 2nd stage & 388 & 31.91 \\
\hline Vocational school & 281 & 23.11 \\
\hline Special primary or high school & 66 & 5.43 \\
\hline Grammar school & 65 & 5.35 \\
\hline 8-year grammar school & 3 & 0.25 \\
\hline Conservatory & 8 & 0.66 \\
\hline Primary school assistant & 3 & 0.25 \\
\hline Educator (school club, etc.) & 2 & 0.16 \\
\hline Special form of teacher at common school & 2 & 0.16 \\
\hline Special pedagogue at a primary school & 12 & 0.99 \\
\hline Total (respondents) & $\mathbf{1 2 1 6}$ & $\mathbf{1 0 0 . 0}$ \\
\hline
\end{tabular}


dents had 17-20 (15\%), 24-26 (11\%), 30-32 (11\%), 33-36 (10\%) of practice.

The descriptive items included questions about the experience with cooperation between teachers and teaching assistants. In total, the question was answered by $\mathrm{N}=569$ respondents: $40.07 \%(\mathrm{n}=228)$ responded yes and $58.35 \%$ $(\mathrm{n}=332)$ responded no.

\section{Results}

This part of the paper presents the results of the survey, specifically, the open questions aimed at identifying the perceived barriers and teachers' needs relate to inclusive education in practice (see Table 2).

Open questions were categorised and processed using the methods of analysis, synthesis, and generalisation.

Due to the large number and diversity of responses, the barriers for inclusive education were categorised into groups. The largest one was barriers generated by the school itself $(28.14 \%)$. The responses were categorised into groups as follows:

barriers generated by the school: understaffing, insufficient material and technical equipment (lack of funding, space, classrooms), failure to embrace the inclusive school concept, incompetent teacher, too many students in the form overloading the teacher;

by the family: lack of family education, parents refuse to cooperate, parents are too demanding or have unrealistic expectations, parents lack interest in their children's education, low attendance, parents refuse to consult experts to tackle their child's problems, geographic and social isolation, fear that the child may be labelled, prejudice, parents of healthy children lack understanding;

by students: low attendance, lack of interest in education, low motivation, negative attitude to school, other students are intolerant (aggressive or insensitive), SSN students are reluctant to join the collective, lack of discipline and compliance with the treatment, exploitation of the SSN status, ignoring the recommendations specified in the individual study plan,

by society/state: lack of funding for assistants, conditions for inclusion are not provided, curricula and syllabi focus on performance, administrative burden, poor legislation, too many students in a form, education system is not a priority, demands for teachers are too high.

Subsequently, the teaching staff was asked to provide their ideas on how to improve inclusive education (Table 3 ).

As can be seen, the responses in Table 2 are related to those in Table 3 . The former question focused on barriers while the latter focused on the need (to remove the barrier).

Teachers involved in this research were also asked about their ideas on how to improve university teacher training to prepare them for working with integrated students and inclusive education. The responses reflect the respondents' own experience with university education $(>70 \%$ of respondents had more than 17 years of teaching practice) as well as their teaching practice. As can be seen, the responses revolve around the same issues. They were

Table 2. Types of barriers for inclusive education according to the teaching staff

\begin{tabular}{|l|c|c|}
\hline & $\mathrm{N}$ & $\%$ \\
\hline Generated by school & 388 & 28.14 \\
\hline Generated by family & 156 & 11.31 \\
\hline Generated by students & 24 & 1.74 \\
\hline Generated by state & 121 & 8.77 \\
\hline Generated by society & 24 & 1.74 \\
\hline Total responses & $\mathbf{7 1 3}$ & $\mathbf{5 1 . 7 0}$ \\
\hline Missing responses & 666 & 48.30 \\
\hline Total & $\mathbf{1 3 7 9}$ & $\mathbf{1 0 0 . 0}$ \\
\hline
\end{tabular}

The number of responses exceeds the number of respondents, because multiple responses could be provided. 
Table 3. What helps the teaching staff implement inclusive education in practice the most?

\begin{tabular}{|l|c|l|c|c|}
\hline \multicolumn{1}{|c|}{ Responses } & $\%$ & & $\mathrm{n}$ & $\%$ \\
\hline \multirow{2}{*}{$\begin{array}{l}\text { Teaching and special- } \\
\text { ised staff }\end{array}$} & 23.57 & $\begin{array}{l}\text { specialised staff (special teachers, curative teachers, psy- } \\
\text { chologists) }\end{array}$ & 185 & 13.42 \\
\cline { 2 - 5 } & teaching assistants (qualified) & 140 & 10.15 \\
\hline \multirow{2}{*}{ Education } & 19.15 & practical examples and demonstrations & 154 & 11.17 \\
\cline { 3 - 6 } & educational activities (workshops, training) & 110 & 7.98 \\
\hline Number of students & 11.60 & lower number of students in the form & 160 & 11.60 \\
\hline \multirow{2}{*}{ Information sources } & 11.09 & $\begin{array}{l}\text { theoretical material - methodological guidelines, manuals, } \\
\text { worksheets for specific subjects, tasks for students with spe- } \\
\text { cific SEN, test collections, databases of learning tasks }\end{array}$ & 153 & 11.09 \\
\hline I do not know & 10.30 & I do not know (I have never considered it, hard to say) & 142 & 10.30 \\
\hline Total responses & 100.0 & & 1379 & 100.0 \\
\hline
\end{tabular}

The unlisted responses were less than $4 \%$ of all responses (the number is too low to be considered relevant). The total number of responses exceeds the number of respondents (multiple responses were possible).

Table 4. What changes in university teacher education are necessary to improve the competences related to integrated education and in inclusion

\begin{tabular}{|c|c|c|}
\hline & $\mathrm{N}$ & $\%$ \\
\hline Improve theoretical and practical preparation & 543 & 39.38 \\
\hline Improve practical preparation & 357 & 25.89 \\
\hline Improve theoretical preparation & 130 & 9.43 \\
\hline Other & 121 & 8.77 \\
\hline I do not know & 65 & 4.71 \\
\hline Total responses & 1216 & 88.18 \\
\hline Missing responses & 163 & 11.82 \\
\hline Total & 1379 & 100.00 \\
\hline
\end{tabular}

The total number of responses exceeds the number of respondents (multiple responses were possible).

categorised into the following groups: practical and theoretical preparation require modification (39\%), practical preparation requires modification (25\%), theoretical preparation requires modification ( $9 \%$ ), see Table 4 .

\section{Discussion}

Based on Table 2, it can be stated that although only half of the respondents answered the question about the barriers for inclusive education, the scope and variability of their responses corresponded with the barriers referred to in theory and research. Most frequently, barriers generated by the schools themselves were referred to $(28 \%$, see Table 2$)$. The failure to accept the inclusive school concept as a barrier referred to by the respondents corresponds with the SSI findings (2018/2019) as well as the broader concept of the inclusion index (Booth $\&$ Ainscow, 2002). Ainscow (2005) has explained that many barriers faced by the teachers result from the established mindset. The mindset and ways of thinking are influenced by the environment. Safe, accepting, and cooperating schools that provide inspiring community environments consider the development of inclusive culture important. Their school culture involves promoting common inclusive values and relationships based on cooperation Booth \& Ainscow (2002). The respective governing 
body is the main stakeholder in the process of transforming the school into an inclusive one 2008; MacFarlane \& Woolfson, 2013; Janoško \& Neslušanová, 2014, p. 77).

According to Cologon, K. (2013, p. 29) as well as Sharma \& Armstrong et al, (2019), barriers for inclusive education include negative attitudes and stigma related to "otherness» and health disadvantage. Lishuai Jia \& Marina Santi (2020) have also pointed out that other students' parents may have negative attitudes as well. Similar responses can be found in this research: the respondents explain that parents fear their SEN child would be «labelled» and other children's parents lack understanding. The teachers involved in this research (62\% of them work at primary schools) believe that the legal representative is responsible for the child's school attendance, therefore attendance issues, lack of discipline (in parent/child), and ignoring recommendations (treatment, individual plan) were included in the group of barriers generated by the student/their family. However, these kinds of barriers (lack of stimulation in the family and interest in education) are not considered relevant in terms of equal treatment or education opportunities provided by the teachers. It seems that teachers consider family an important factor affecting the student's attitude to inclusion and in turn, its success. In terms of inclusion research, European studies focused on family as well (the role of parents in educational inclusion, see EASIE, 2003). Barriers for inclusion generated by students (mainly behavioural) are quite challenging for the teachers (EASIE, 2003, p. 14). Slovak teachers repeatedly referred to certain student characteristics (which could be generalised as behavioural issues), which make inclusive education more difficult. System barriers including insufficient funding and support from the governing bodies (Cologon, 2013, p. 29) have also been referred to by the respondents. EASIE (2003) has explained that an appropriate funding system is of key importance. $8 \%$ of teachers in this research pointed out certain barriers out of their control (poor legislation, lack of funding, curricula and syllabi focused on performance, administrative burden, too many students in the form) The findings of this research are in line with those of the Learning Makes Sense research project (Miškolci) in which $22.4 \%$ of teachers specified «too much other work» as the biggest barrier. OECD TALIS2013 and 2018 have revealed that teachers spend more than half of their working time on non-teaching activities such as administrative work (Miškolci). Another barrier was the form size (large number of students). Some EU countries consider the form size an important factor in inclusion (EASIE, 2003, p. 14).

The needs of teachers working in inclusive environments are closely related to these barriers. For instance, the barrier described as understaffing (Table 2, see barriers generated by the school) turned into the need for specialised staff and cooperation with experts. (13\% specified psychologists, special teachers, curative teachers, or a whole team; $10 \%$ specified a teaching assistant). $23 \%$ of respondents described the need for a teaching or specialised staff member available for cooperation. The situation is similar in other countries as well (Lishuai Jia \& Santi, 2020; Sharma \& Armstrong et al, 2019). Besides the form size, the teachers' need to cooperate with specialised staff or other experts can result from their lack of knowledge on inclusive education and opportunities for their own professional development. As it was explained in the theoretical background, this barrier is common across different countries, see e. g., Cologon (2013), Lishuai Jia \& Marina Santi (2020), Sharma \& Armstrong et al. (2019).

The second largest group of responses (19.15\% - need for education) can be interpreted as positive in terms of the respondents' attitude to life-long learning. The nature (contents) of education referred to by the respondents varies. $11 \%$ of teachers are interested in further practical education, want to gain more practical experience; practical training, advice, and examples; they would like to see other teachers demonstrating how to deal with different situations, specific ways to work with SEN students. They would like to attend practical training organised by an educational institution and visit schools where inclusive education has been successfully implemented, they are even interested in internships at such schools, etc. 
$7.98 \%$ of teachers were interested in accessible further education provided by an organisation, regular specialised training or re-training providing meaningful and quality further education reflecting their current needs. Again, these findings correspond with the OECD TALIS2018 results for the SR (e. g., dire need for further education focused on teaching SEN students $-26.5 \%$, behaviour and classroom leadership - $19.1 \%$ ) (NÚCEM, TALIS2018, p. 3). Another group of teachers refers to their need for information and knowledge sources (see Table 3 and Miles, 2000) in the form of methodology, guidelines, manuals, information databases $(11 \%)$. Teachers would like to use them individually and since they cannot get physical copies, specialised information for SEN teachers should be made available mainly through ICT. The efficient use of ICT in working with SEN students has been addressed in EASIE (2003). As can be seen, the barrier represented by too many students in the form (Table 2) turned into the need for reducing the number of students in the form (11\%, see Table $3)$. Although it requires a complex system and legislative change, it would reduce the teachers' workload. The number of integrated students in a common primary school form was previously specified by Decree of the Ministry of Education of the SR No. 320/2008 Coll. on primary schools (Section 13, Paragraph 2) - a maximum of 3 students with a health disadvantage could be integrated into a single form. However, it was amended by Decree of the Ministry of Education of the SR No. 224/2011, which modified the integration of students in common forms (Section 13, Paragraph 2 of Decree No. 320/2008 Coll. on primary schools) as follows: "for each student with a health disadvantage integrated into the form, the maximum number of other students in the form is hereby reduced by two pursuant to Section 29, Paragraph 5. The amendment is related to the changes introduced by Act No. 188/2015 Coll. which amended Act No. 245/2008 Coll. on education and upbringing (School Act) on the amendments and changes to certain Acts. Another goal was to reduce the administrative burden at primary schools: "The provision reducing the number of students in the form for the purpose of in- clusion of students with health disadvantage is hereby removed.» The provision specifying the number by which the total number of students in the form is reduced if students with health disadvantage are included has been removed. The School Act in force specifies the minimum number of pupils in the form. If the provision currently in force is retained, newly created forms will not reach the minimum number of students and it will be difficult for the schools to cover the incurred costs. The schools will still receive more money for SEN students and students with extraordinary intellectual talents.

$40 \%$ of teachers agree that university teacher education needs to be modified in terms of both theory and practice (see Table 4). In particular, the teachers proposed the following changes: adjust the number of lessons in favour of practical preparation from the very beginning of the university study, provide professional field practice at different schools (including the special ones) and focus on SEN students so that teaching students can try out the methods and strategies focused on working with SEN students (as teachers and teaching assistants alike). Theoretical preparation should reflect the actual practice and needs so that teaching students acquire more knowledge about special pedagogy and inclusion (as a separate course), psychology, psychodidactics, and training. They should learn about these aspects from model situations, experts from the practice, lesson demonstrations, and at schools where inclusion has been successful. They should also study applied subject didactics addressing SEN students, visit a variety of facilities, and get hands-on experience with the documentation of the integrated students.

The variety of responses in the "Other» section was so large that it is impossible to perform a statistical analysis. They ranged from teacher training should not be modified at all, integration should not be performed at all costs, I do not agree with inclusion to the whole system needs a change, or a complex reform of funding is necessary to achieve inclusion. However, some responses were selected as they are relevant. Other teachers' ideas on how to improve university teacher training to prepare teachers for integration/inclusion included the 
following: improve the teachers' quality to reflect the practice - increasing number of SEN students; develop motivation, interest, and attitude; develop students personalities in terms of respect and tolerance, honest communication, socialisation, and participation - graduates should also be able to develop these aspects in their own students; learn to accept the student as they are; modify the educational programme to address the students' needs, their possibilities, and potential; establish a separate field of study to address this area (integration, inclusion, special pedagogy); have an expert in SEN methodology who can work with students with different abilities. Teachers also repeatedly claimed that the family environment and parents' attitude strongly affect the course of integration and called for a change to address the child's background to introduce positive changes. Based on these findings, it is recommended to involve school experts to address the social relationships within the students' families. Many of these requests (mainly efficient cooperation with the family) could be addressed in cooperation with specialised staff - social teachers, special teachers, and school psychologists.

\section{Conclusion}

One of the preconditions for successful inclusive education is undoubtedly quality professional training of future teachers and a variety of further education in this area. Insufficient university training or continuous teacher education as well negative attitudes of the teachers to inclusive education generate barriers, which prevent successful implementation of inclusive education in practice. University teacher training is the first step in their life-long learning. The graduate's knowledge is not final, further education is desirable. Inclusive education is accompanied by daily changes and constant development; therefore, the teacher must have the abilities necessary to cope with it. In the course of their career, they need to respond to the changing needs (European Agency for Development in Special Needs Education, 2012). The European Agency for Development in Special Needs Education (2012) has created an «inclusive teacher profile» specifying four key values related to individual teacher competences. The key values are in line with the 21st model of a learning society, which aims to replace the knowledge-based society. The former requires knowledge, skills, and attitudes - the KSA model (Alkhalaf, 2013). The values adhered to by teachers are of key importance in accepting students' diversity and helping to build a modern, open, and flexible process of education and upbringing to guarantee high quality and efficient education.

\section{References}

Ainscow, M. (2005). Developing inclusive education systems: What are the levers for change? Journal of Educational Change. 6(2), 109-124. https://doi.org/10.1007/s10833-005-1298-4

Alkhalaf, S. (2013). Measuring the Information Quality of e-Learning Systems in KSA: Attitudes and Perceptions of Learner. https://link.springer.com/chapter/10.1007/978-3-642-37374-9_75.

Belková, V. \& Zólyomiová, P. (2018). Inkluzívne vzdelávanie a praktické skúsenosti učitel’ov. In Kosturková, M., Ferencová, J., Ištvan, I., \& Rovňanová, L. (eds.), Vybrané aspekty pedagogickej profesie Zborník vedeckých štúdií. Prešov: PU, pp. 18-27. [CD-ROM].

Belková, V., Zólyomiová, P. \& Veselovská, L. (2018). Názory a skúsenosti učitel’ov s prípravou a d’alším vzdelávaním v oblasti práce so žiakmi so špeciálnymi potrebami v podmienkach bežných škôl. Šimáne, M. \& Danielová, L. (Ed.) Sborník z medzinárodné konference ICOLLE2018. Brno: Mendelova univerzita. pp. 20-31. https://www.icolleconference.cz/files/sbornik-icolle-2018.pdf

Belková, V. \& Zólyomiová, P. (2019). Potreba vytvárania inkluzívneho prostredia v súčasnej škole. Edukácia ved Belková, V., Petrík, Š. \& Zólyomiová, P. (2020). Teachers opinions and experiences with an inclusive school enviroment. Ad Alta, Vol. 10, Iss. 02 (10/02), pp. 261-268I. ISSN2464-6733(Online). doi. org/10.33543/1002.

Booth, T. \& Ainscow, M. (2002). Ukazovatel inkluze. CSIE, UK. ISBN1 87200118 1. Czech translation. 
Čechová, H. \& Zítková, D. (2007). Ukazovatel inkluze. Rytmus, 2007. http://www.csie.org.uk/resources/translations/IndexCzech.pdf

Brozmanová Gregorová, A., Hudecová, A., Jusko, P., Kurčíková, K., Maková, A., Nemcová, L., Papšo, P., Stachoň, M., Šavrnochová, M. \& Šolcová, J. (2017). Správa o potrebách detí a mládeže v meste Banská Bystrica podklady pre tvorbu mládežníckej politiky v meste. Banská Bystrica: Centrum dobrovol'níctva. ISBN978-80-972659-6-0.

Cologon, K. (2013). Inclusion in education towards equality for students with disability. Australian Government Department of Education to expand the education policy capacity of Children with Disability Australia. https://d1wqtxts1xzle7.cloudfront.net/34251940/CDA_Issues_Paper_on_Inclusion.pdf

Čerešňová, Z. et.al. (2018). Inclusive higher education. Praha: Gasset - Allan Gintel.

European Agency for Development in Special Needs Education (2003). Special Needs Education in Europe. Cor Meijer, Victoria Soriano, Amanda Watkins (eds.). Odense, Denmark. ISBN: 87-90591-77-1.

European Agency for Development in Special Needs Education (2012). Profile of Inclusive Teachers. Odense, Denmark. European Agency for Development in Special Needs Education. https://www. european-agency.org/sites/default/files/te4i-profile-of-inclusive-teachers_Profile-of-Inclusive-TeachersSK.pdf

European Agency for Development in Special Needs Education (2014a). Organizácia opatrení na podporu inkluzivvneho vzdelávania - súhrnná správa. Odense, Denmark. European Agency for Development in Special Needs Education//www.european-agency.org/Sloven\%C4 \%8Dina/publications

European Agency for Development in Special Needs Education (2014b). Pät'kl'účových myšlienok pre inkluzívne vzdelávanie. Uvedenie teórie do praxe. Odense, Denmark: European Agency for Development in Special Needs Education//www.european-agency.org/Sloven\%C4 \%8Dina/publications

European Agency for Development in Special Needs Education (2016). Opatrenia pre inkluzivne vzdelávanie: Úvahy a návrhy delegátov. Odense, Denmark: European Agency for Development in Special Needs Education. https://www.european-agency.org/Sloven\%C4 \%8Dina/publications

European Agency for Development in Special Needs Education (2017). European Agency Statistics on Inclusive Education: 2014 Dataset Cross-Country Report. (J. Ramberg, A. Lénárt, and A. Watkins, eds.). Odense, Denmark. http://www.european-agency.org/sites/default/files/EASIE\%202014 \%20Dataset\%20 Cross-Country\%20Report_1.docx

Humphrey, N. \& Symes, W. (2011). Inclusive education for pupils with autistic spectrum disorders in secondary mainstream schools: teacher attitudes, experience and knowledge. International Journal of Inclusive Education, 17(1), pp. 32-46. DOI: 10.1080/13603116.2011.580462

Janoško, P. \& Neslušanová, S. (2014). Škola s inkluzívnou klímou. Ružomberok: VERBUM - vydavatel'stvo KU.

https://www.europeanagency.org/sites/default/files/Janosko_Neslusanova_Skola_s_inkluzivnou_ klimou.pdf

Körnerová, I. et al. Smerom k inkluzívnemu vzdelávaniu. Úspešné príklady inkluzívneho vzdelávania v praxi. Inclusion Europe s podporou Európskej komisie. www.zpmpvsr.sk ' dokumenty Inkluzivne_ vzdelavanie preklad

Koršñáková, P., \& Kováčová, J. (2010). Prax učitelov slovenských škôl na nižšom sekundárnom stupni z pohladu medzinárodného výskumu OECD TALIS2008. Národná správa. Bratislava: NÚCEM - National Institute for Certified Educational Measurements http://www.nucem.sk/documents//27/medzinarodne merania/talis/publikacie/TALIS-web.pdf

Leonhardt \& Lechta et al. (2006). Inkluzívna pedagogika ako odbor, princíp i politikum versus jej realizácia. Efeta, 17(2), 2-4. ISSN1335-1397

Lishuai Jia \& Santi, M. (2020). Chinese regular classroom teachers' understanding of barriers to inclusive education. In Italian Journal of Special Education for Inclusion. ISSN2282-6041. DOI: 10.7346/ sipes-01-2020-17

Machalová, M. (2018.) Bariéry v edukácii sociálnych klientov. Prohuman, November. https://www. prohuman.sk/socialna-praca/bariery-v-edukacii-socialnych-klientov 
MacFarlane, K. \& Woolfson, L.M. (2013). Teacher attitudes and behavior toward the inclusion of children with social, emotional and behavioral difficulties in mainstream schools: An application of the theory of planned behavior, w: Teaching and Teacher Education, Vol. 29, pp. 46-52. https://doi.org/10.1016/j. tate.2012.08.006

Miles, S. (2000). Overcoming Resource Barriers: The challenge of implementing inclusive education in rural areas. A Symposium on Development Policy entitled, "Children with Disabilities and the Convention on the Rights of the Child». Gustav Stresemann Institute, Bonn, Germany, October 27-29, 2000.

Ministry of Finance of the Slovak Republic Metodický pokyn na použitie odborných výrazov pre oblast' informatizácie spoločnosti. [Methodological Instruction on Using Specialised Terminology in the Area of Society Informatisation] http://www.informatizacia.sk/ext_dok-metodicky_pokyn_glosar_pojmov $13482 \mathrm{c}+\& \mathrm{~cd}=5 \& \mathrm{hl}=\mathrm{sk} \& \mathrm{ct}=\mathrm{clnk} \& \mathrm{gl}=\mathrm{sk} \& \mathrm{client}=$ firefox-b-e

Miškolci, J. Prekážky v profesijnom rozvoji. In Analýza zistení o stave školstva na Slovensku, projekt To dá rozum. https://analyza.todarozum.sk/docs/331119001bfla/MESA10 - (project implementer): Learning Makes Sense. https://todarozum.sk

NÚCEM. Press release on main findings, TALIS2018 Slovakia. https://www.nucem.sk/dl/4449/ TALIS $\% 202018 \% 20$ tlacova $\% 20$ sprava.pdf

OECD TALIS2013. (2014). Results: an international Perspective on Teaching and learning. OECD Publishing.http://www.oecd-ilibrary.org/education/a-teachers-guide-to-talis-2013_9789264216075-en

OECD TALIS2018. Teaching and Learning International Survey Bratislava: NÚCEM. www.nucem. sk/sk/filemanager/download/6285/3/brozura-talis-2018

NÚCEM, TALIS2018. https://www.nucem.sk/sk/merania/medzinarodne-merania/talis/cyklus/2018

Rajovic, V. \& Jovanovic, O. (2013). The Barriers to Inclusive Education: Mapping 10 Years of Serbian. In Teachers' Arritudes Toward Inclusive Education. Journal of Special Education and Rehabilitation, 14 (3-4), 78-97. ISSN1409-6099. http://doi.org/10.2478/JSER-2013-001210.2478

Riehl, C., J. (2008). The Principal's Role in Creating Inclusive Schools for Diverse Students: A Review of Normative Empirical, and Critical Literature on the Practise of educational Administration. Journal of Education, 189 (1/2), 183-197. ISSN0022-0574.

Sharma, U., Loreman, T. \& Forlin, Ch. (2012). Measuring techaer efficacy to implement inclusive practices. Journal of Research in Special Educational Needs Education, 12(1), 12-21.

https://www.academia.edu/18421635/Measuring_teacher_efficacy_to_implement_inclusive_practices

Sharma, U., Ann Cheryl Armstrong, Laisiasa Merumeru, Janine Simi \& Hannah Yared. (2019). Addressing barriers to implementing inclusive education in the Pacific. In International Journal of Inclusive Education, 23:1, 65-78, DOI: 10.1080/13603116.2018.1514751

SSI - State School Inspection Správa o podpore inkluzivneho vzdelávania žiakov ZŠ v SR v školskom roku 2018/2019 [Report on the Promotion of Inclusive Education for Primary School Pupils in the 2018/2019 School Year] https://www.ssiba.sk/admin/fckeditor/editor/userfiles/file/Dokumenty/SPRAVY/2019/129_Inkluzia_Sprava\%20SR_fin.pdf/df

Špotáková, M., Kundrátová, B., Štefková, M., Vojtová, Z. \& Zikmund Perašínová, D. (2018). Od integrácie $k$ inklúzii. Information brochure for primary school teachers. Bratislava: VÚDPaP. [online]. https://www.minedu.sk/data/att/14615.pdf

Vančíková, K., Sabo, R. \& et.al. (2018). Inkluzívne vzdelávanie - skúsenosti slovenských škôl. Banská Bystrica: Belianum.

Vyhláška Ministerstva školstva Slovenskej republiky č. 320/2008 o základnej škole [Decree of the Ministry of Education of the SR. No. 320/2008 on primary schools].

https://www.slov-lex.sk/pravne-predpisy/SK/ZZ/2008/320/20150901

Vyhláška Ministerstva školství, vedy, výskumu a športu Slovenskej republiky č. 224/2011, ktorou sa mení a doplña vyhláška Ministerstva školstva Slovenskej republiky č. 320/2008 Z.z. o základnej škole. [Decree of MoESRaS No. 224/2011 on amendments and changes to Decree of the Ministry of Education of the SR. No. 320/2008 on primary schools]

https://www.slov-lex.sk/pravne-predpisy/SK/ZZ/2011/224/ 
Basic information on the OECD TALIS2013 results. http://www.nucem.sk/documents//27/medzinarodne_merania/talis/publikacie/ine/TALIS_2013_prvotne_zistenia.pdf

Zákon č. 245/2008 Z.z. o výchove a vzdelávaní (školskýzákon) a o zmene a doplnení niektorých zákonov v zneni neskoršich predpisov. [Act No. 245/2008 Coll. on education and upbringing (School Act) on the amendments and changes to certain Acts]. www.minedu.sk

Zákon č. 188/2015 Z.z., ktorým sa meni a dopľna Zákon č. 245/2008 Z.z. o výchove a vzdelávani (školský zákon) a o zmene a doplnení niektorých zákonov v zneni neskoršich predpisov. [Act No. 188/2015 Coll. on the amendments and changes to Act No. 245/2008 Coll. on education and upbringing as amended.] www.minedu.sk 